\title{
Faktor - Faktor yang Memengaruhi Profitabilitas pada Perusahaan Subsektor Investment Company di BEI Periode 2015 - 2019
}

\author{
Reny Aziatul Pebriani ${ }^{1)}$, Rafika Sari ${ }^{2)}$ \\ ${ }^{1), 2)}$ Program Studi Akuntansi, Universitas Indo Global Mandiri, Palembang \\ Email: renyaziatul@uigm.ac.id ${ }^{1)}$,rafikasari@uigm.ac.id ${ }^{2)}$
}

\begin{abstract}
The aim of this study is to determine and analyse the effect of ESOP, leverage, and the size of the company partially and simultaneously to the profitability of the Investment Company Subsector Company in IDX Period 2015-2019. The data used in this study is library studies and documentation. Sample selection in this study using nonprobability purposive sampling technique. The data analysis method used is multiple linear regression analysis. The results prove that ESOP and company size partially have no significant effect on profitabilitas, but leverage has a significant effect on profitability. Then simultaneously ESOP, Leverage, and Company Size have no effect on profitability. The results of research with Agency theory and signal theory, ESOP is expected to increase the loyalty of the company manager to the owner of the company in improving profitability, and ESOP does not affect the contribution of profitability information of a company in assessing the condition of a company, between the relationship of the manager and the owner of the company. Leverage, in the explanation of signal theory is one of the factors that influence in providing information to investors on the profitability of acompany. Size of the company is determined by the management steps to manage the company's profit as best as possible, which we know companies with large scale does not necessarily have a good company performance also in improving its profitability. This research is expected to help companies to improve the profitability of thecompany.
\end{abstract}

Keywords: ESOP, leverage, company size, profitabilitas.

\section{ABSTRAK}

Tujuan dari penelitian ini untuk mengetahui dan menganalisa pengaruh Employee Stock Ownership Program (ESOP), leverage, dan ukuran perusahaan secara parsial maupun simultan terhadap profitabilitas Perusahaan Subsektor Investment Company di BEI Periode 2015-2019. Data yang digunakan pada penelitian ini adalah studi pustaka dan dokumentasi. Pemilihan sampel pada penelitian ini dengan menggunakan teknik nonprobability purposive sampling. Metode analisis data yang digunakan adalah analisis regresi linear berganda. Hasil penelitian membuktikan bahwa secara parsial ESOP dan Ukuran Perusahaan tidak berpengaruh signifikan terhadap Profitabilitas, namun Leverage berpengaruh signifikan terhadap profitabilitas. Kemudian secara simultan ESOP, Leverage, dan Ukuran Perusahaan tidak berpengaruh terhadap profitabilitas. Hasil penelitian dengan Agency theory dan teori sinyal, dimana dalam Agency theory menyatakan dengan adanya ESOP diharapkan mampu meningkatkan loyalitas pengelola perusahaan (agen) kepada pemilik perusahaan (prinsipal) dalam meningkatkan profitabilitas, dalam teori sinyal pula ESOP tidak memberikan pengaruh dalam kontribusi mengenai informasi profitabilitas suatu perusahaan dalam menilai kondisi suatu perusahaan, antara hubungan pengelola dengan pemilik perusahaan. Leverage, pada pada penjelasan teori sinyal merupakan salah satu faktor yang berpengaruh dalam memberikan informasi kepada investor terhadap profitabilitas suatu perusahaan. Skala ukuran perusahaan ditentukan oleh langkah manajemen untuk mengelola laba perusahaan sebaik mungkin, yang mana kita ketahui perusahaan dengan skala besar belum tentu memiliki kinerja perusahaan yang baik pula dalam meningkatkan profitabilitasnya. Penelitian ini diharapkan dapat membantu perusahaan untuk meningkatkan profitabilitas perusahaan.

Kata Kunci : ESOP, leverage, ukuran perusahaan, profitabilitas.

\section{Pendahuluan}

Tujuan dari didirikannya perusahaan adalah salah satunya untuk memperoleh keuntungan dan mempertahankan eksistensi perusahaan, dengan cara meningkatkan seluruh aktivitas perusahaan dan mengoptimalkan sumber daya yang dimiliki agar perusahaan mencapai laba yang maksimal. (Dwiyanthi \& Sudiartha, 2017). Untuk mengukur efisiensi aktivitas suatu perusahaan dalam memperoleh laba dapat diukur dengan menggunakan rasio profitabilitas (Sukmayanti \& Triaryati, 2019).

Penelitian yang dilakukan (Pebriani et al., 2020) menyatakan bahwa baik buruknya kinerja suatu perusahaan dapat dinilai dengan profitabilitas perusahaan, dimana profitabilitas merupakan salah 
satu faktor dalam menilai kinerja suatu perusahaan. dengan adanya profitabilitas suatu perusahaan dapat diketahui dalam periode tertentu, kemampuan perusahaan dalam menghasilkan laba pada tingkat penjualan, aset dan modal saham.

Banyak faktor yang menjadi pengaruh profitabilitas suatu perusahaan. Salah satunya yakni aspek kepemilikan saham oleh karyawan, perusahaan yang melakukan Employee Stock Ownership Program (ESOP) merupakan salah satu bentuk kepemilikan manajerial yang dapat dilakukan oleh perusahaan. Selain meningkatkan rasa kepemilikan manajerial kepada karyawan, ESOP juga diharapkan mampu menjadikan karyawan dapat menyampaikan informasi yang lebih memadai. Hal ini dikarenakan karyawan pada perusahaan yang telah mengadopsi ESOP tidak lagi bertindak sebagai karyawan tetapi juga sebagai pemilik atau investor (Budiman \& Wahidahwati, 2017).

Terdapat beberapa penelitian terdahulu mengenai pengaruh ESOP terhadap kinerja perusahaan yang diukur melalui Return On Asset (ROA). Penelitian yang dilakukan oleh (Haosana \& Hatane, 2015), dengan hasil penelitian menyatakan bahwa variabel ESOP berpengaruh positif signifikan terhadap ROA, hal tersebut menunjukkan apabila perusahaan menerapkan program ESOP maka ROA perusahaan juga meningkat. Pernyataan berbeda juga ditunjukkan oleh penelitian (Isbanah, 2015) dari hasil penelitianya menunjukkan bahwa ESOP terbukti tidak berpengaruh terhadap ROA.

Perusahaan dengan pertumbuhan yang tinggi tentunya memerlukan dana yang tidak sedikit untuk membiayai aktivitas operasional perusahaannya. Leverage adalah salah satu faktor penting yang memengaruhi profitabilitas karena leverage bisa digunakan perusahaan untuk meningkatkan modal perusahaan dalam rangka meningkatkan keuntungan (Putra \& Badjra, 2015).

Terdapat beberapa penelitian terdahulu mengenai leverage seperti penelitian dari (Isbanah, 2015) yang menyatakan bahwa pada variabel leverage berpengaruh dan signifikan terhadap Return on Asset (ROA) Sedangkan berbeda dari penelitian (Istyawati \& Purwohandoko, 2019) yang menyatakan bahwa leverage tidak berpengaruh terhadap profitabilitas.
Faktor lain yang juga sangat penting dalam memengaruhi profitabilitas yakni ukuran perusahaan. Ukuran Perusahaan adalah salah satu variabel yang dipertimbangkan dalam menentukan nilai suatu perusahaan. Ukuran perusahaan merupakan cerminan total dari aset yang dimiliki suatu perusahan. Perusahaan sendiri dikategorikan menjadi dua jenis, yaitu perusahaan berskala kecil dan perusahaan berskala besar (Pratama \& Wiksuana, 2016). Perusahaan dengan ukuran besar dianggap mempunyai risiko yang lebih kecil, karena perusahaan dengan ukuran besar dianggap lebih memiliki akses ke pasar modal sehingga lebih mudah untuk memperoleh tambahan dana yang kemudian dapat meningkatkan profitabilitas perusahaan (Sukmayanti \& Triaryati, 2019).

Terdapat adanya beberapa penelitian terdahulu mengenai ukuran perusahaan terhadap profitabilitas seperti penelitian yang dilakukan oleh (Dewi \& Candradewi, 2018) yang menyatakan bahwa hasil penelitiannya menunjukkan bahwa ukuran perusahaan berpengaruh positif dan signifikan terhadap kinerja keuangan perusahaan. Sedangkan berbanding terbalik dari hasil penelitian yang dilakukan oleh (Istyawati \& Purwohandoko, 2019) yang menyatakan bahwa hasil penelitiannya menunjukkan bahwa ukuran perusahaan tidak berpengaruh dan signifikan terhadap profitabilitas.

Didalam Bursa Efek Indonesia terdapat Sektor Trade, Services, And Investment, yang memiliki 9 subsektor yakni salah satunya adalah subsektor investment company. Salah satu faktor yang dapat mendorong pertumbuhan ekonomi yaitu Investasi. Investasi merupakan salah satu solusi dari permasalahan yang ada dalam hal ekonomi, yakni dengan semakin berkembangnya zaman tentunya banyak hal yang harus dipersiapkan mengenai keperluan jangka panjang maupun jangka pendek, dengan berinvestasi sama halnya dengan mempersiapkan masa depan, karena semua orang membutuhkan investasi yang bertujuan untuk melindungi asetnya dari penurunan nilai akibat inflasi.

Semakin berkembangnya zaman, tingkat masyarakat untuk melakukan investasi mengalami perkembangan, dapat dilihat dari data Badan Koordinasi Penanaman Modal (BKPM), Realisasi Investasi Indonesia 2019 Naik 48,4\% dalam 5 Tahun (Jayani, 2020).

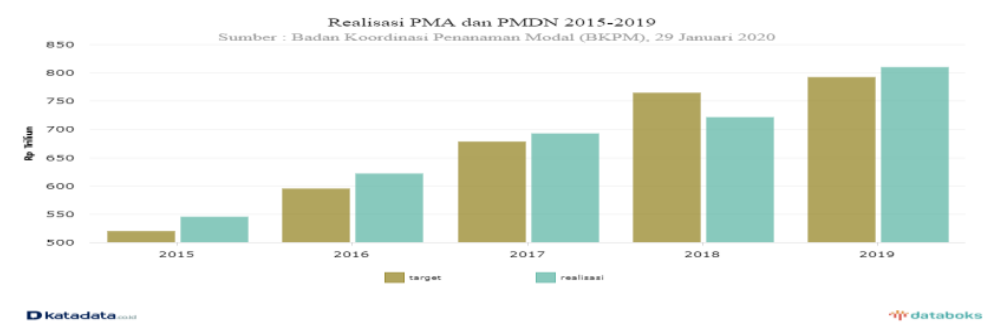

Gambar 1. Realisasi Investasi Indonesia dalam 5 tahun

Sumber:Badan Koordinasi Penanaman Modal (BKPM), Databoks.Katadata.Co.Id 
Seiring meningkat dan berkembangnya investasi pula menyebabkan timbulnya investasiinvestasi ilegal yang menyebabkan masyarakat kesulitan memilih investasi yang baik dan benar (Hastuti, 2020). Sehingga perusahaan investasi yang terdaftar di BEI selain ingin perusahaannya terus berkembang, perusahaan juga ingin meningkatkan profitabilitas keuangannya agar memperoleh minat dan kepercayaan masyarakat terhadap perusahaan investasi. Berikut ini adalah gambaran dari kinerja keuangan perusahaan yang diukur menggunakan ROA pada perusahaan subsektor Investment Company di Bursa Efek Indonesia (BEI) tahun 2015-2019 sebagai berikut:

Table 1. ROA Investment Company 2015 - 2019

\begin{tabular}{|l|l|c|c|c|c|c|}
\hline \multirow{2}{*}{ Kode Perusahaan } & \multicolumn{5}{|c|}{ Nama Perusahaan } & \multicolumn{5}{c|}{ ROA (\%) } \\
\cline { 3 - 7 } & & $\mathbf{2 0 1 5}$ & $\mathbf{2 0 1 6}$ & $\mathbf{2 0 1 7}$ & $\mathbf{2 0 1 8}$ & $\mathbf{2 0 1 9}$ \\
\hline ABMM & ABM INVESTAMA Tbk & $-3,81$ & 0,64 & 0,36 & 7,9 & 0,45 \\
\hline BHIT & MNC INVESTAMA Tbk & $-1,1$ & 1,53 & 0,93 & 1,68 & 3,62 \\
\hline BMTR & GLOBAL MEDICOM Tbk & 1,07 & 3,19 & 3,8 & 4,67 & 7,68 \\
\hline BNBR & BAKRIE DAN BROTHERS Tbk & $-18,72$ & $-55,83$ & $-18,15$ & $-8,72$ & 6 \\
\hline MLPL & MULTIPOLAR Tbk & $-5,48$ & 1,3 & $-9,1$ & $-9,44$ & $-6,99$ \\
\hline PLAS & POLARIS INVESTAMA Tbk & $-2,9$ & $-5,5$ & $-3,87$ & 0,22 & 0,2 \\
\hline POOL & POOL ADVISTA INDONESIA Tbk & 5,28 & 30,41 & 24,75 & $-4,71$ & $-67,61$ \\
\hline SRTG & SARATOGA INVESTAMA SEDAYA Tbk & 8,7 & 22,69 & 11,68 & $-30,5$ & 27,54 \\
\hline
\end{tabular}

Sumber: www.idx.com

Pada Tabel menunjukkan bahwa data ROA perusahaan subsektor investment company di BEI tahun 2015-2019 berfluktuasi. Dari data ROA diatas, perusahaan subsektor investment company di BEI tahun 2015-2019 yang berfluktuasi menyebabkan peneliti ingin meneliti lebih lanjut mengenai apa saja faktor-faktor yang dapat mempengaruhi profitabilitas, yang diukur dengan menggunakan ROA. Permasalahan yang ada di dalam perusahaan subsektor investment company di BEI tahun 2015-2019 menyebabkan penelitian ini tertarik menggunakan perusahaan pada subsektor investment company di BEI tahun 20152019 sebagai objek penelitian.

Berdasarkan latar belakang yang telah diuraikan, ditemukan perbedaan hasil penelitian yang ditunjukan antara variabel ESOP, Leverage, dan ukuran perusahaan terhadap profitabilitas. Oleh karena itu, peneliti tertarik untuk meneliti kembali "faktor-faktor yang memengaruhi profitabilitas pada perusahaan subsektor Investment Company di BEI Periode 2015-2019”.

\section{Landasan Teori}

\subsection{Teori Keagenan}

Agency theory mendasarkan hubungan kontrak antar anggota dalam perusahaan, dengan principal (pemilik) dan agent (agen) sebagai pelaku utama. Prinsipal merupakan pihak yang memberikan mandat kepada agen untuk bertindak atas nama prinsipal, sedangkan agen merupakan pihak yang diberi amanat oleh principal untuk menjalankan perusahaan (Setyaningrum, 2016 ; Hidayat, 2016).

\subsection{Teori Sinyal}

Teori sinyal merupakan teori yang diperkenalkan pertama kali oleh spence tahun 1973 dalam penelitiannya berjudul Job Market Signalling. Yakni dalam teori ini melibatkan dua pihak antara manajemen dan investor luar untuk memberikan sinyal. Pihak manajemen berusaha dalam memberikan informasi lengkap kepada investor sehingga investor nantinya bisa menyesuaikan keputusan berdasarkan sinyal yang diterima (Supriadi, 2020 ; Patmawati, 2017).

\subsection{Profitabilitas}

Penelitian yang dilakukan (Pebriani et al., 2020) menyatakan bahwa baik buruknya kinerja suatu perusahaan dapat dinilai dengan profitabilitas perusahaan, dimana profitabilitas merupakan salah satu faktor dalam menilai kinerja suatu perusahaan. dengan adanya profitabilitas suatu perusahaan dapat diketahui dalam periode tertentu, kemampuan perusahaan dalam menghasilkan laba pada tingkat penjualan, aset dan modal saham.

Rasio Return on Assets (ROA) merupakan indikator keberhasilan perusahaan atas pengelolaan kekayaan (aset) yang dimilik perusahaan, sehingga dengan meningkatnya Rasio return on assets (ROA) mencerminkan kinerja perusahaan baik dalam mengelola kekayaan yang dimilikinya, sehingga dapat menghasilkan keuntungan atau laba (Surya et al., 2017 ; Purnamasari, 2017). Rumus dari Return on Assets (ROA) dari penelitian ini yakni

$$
\mathrm{ROA}=\frac{\text { Laba Bersih Setelah Pajak }}{\text { Total aset }} \times 100 \%
$$

2.4. Employee Stock Ownership Program (ESOP) ESOP merupakan suatu program kepemilikan 
saham oleh karyawan perusahaan yang diharapkan dapat meningkatkan sense belonging yang dapat mendukung peningkatan Profitabilitas sehingga program ini memberikan pengaruh positif pada investor yang ditunjukkan melalui peningkatan harga pasar saham (Kartikasari \& Astika, 2015). Dalam penelitian ini ESOP dinyatakan sebagai variabel dummy karena berukuran non-metrik atau kategori. Perhitungan kepemilikan saham ESOP ini dihitung dengan menggunakan skor, yaitu perusahaan yang mengadopsi ESOP diberi kode satu (1) sedangkan yang tidak mengadopsi ESOP diberi kode nol (0).

\subsection{Leverage}

Penelitian yang dilakukan oleh (Isbanah, 2015) menjelaskan bahwa leverage merupakan pengukur aktiva yang dibiayai dengan hutang. Hutang yang digunakan untuk membiayai aktiva berasal dari kreditor, bukan dari pemegang saham ataupun investor.

Debt to Asset Ratio adalah salah satu dari rasio Leverage dimana rasio Leverage merupakan rasio yang digunakan untuk mengukur kemampuan perusahaan untuk melunasi seluruh kewajibannya dengan menggunakan seluruh aset yang dimiliki perusahaan (Pribadi, 2018 ; Trianto, 2018), rumus dari Debt to Asset Ratio dari penelitian ini yakni :

$$
\text { Debt Ratio }=\frac{\text { Total Debt }}{\text { Total Assets }} \times 100 \%
$$

\subsection{Ukuran Perusahaan}

Ukuran perusahaan dianggap mampu mempengaruhi profitabilitas perusahaan, karena semakin besar ukuran atau skala perusahaan maka akan semakin besar pula kesempatan perusahaan memperoleh sumber pendanaan, baik yang bersifat internal maupun eksternal. Perusahaan yang berskala besar cenderung akan menarik minat investor karena akan berpengaruh terhadap perkembangan perusahaan nantinya (Pangestuti \&
Oetomo, 2016 ; Meiriasari, 2017), rumus yang digunaan pada penelitian ini yakni :

$$
\text { SIZE }=\text { Ln (Total Aset })
$$

\section{Metodelogi}

Penelitian ini merupakan penelitian kuantitatif. Metode kuantitatif yaitu suatu metode penelitian yang didasarkan oleh filsafat yang digunakan untuk eksperimen populasi dan sampel tertentu. dalam pengumpulan datanya, menggunakan suatu instrumen penelitian, dengan tujuan untuk menguji hipotesis yang telah ditetapkan berdasarkan analisis data kuantitatif atau statistik (Sugiyono, 2017). Jenis data yang digunakan dalam penelitian ini adalah data sekunder yaitu data berupa angka dan dapat diukur serta diuji dengan metode statistik. Sedangkan sumber data yang digunakan yaitu berupa data dokumentasi. Pada penelitian ini metode pengumpulan data yang digunakan adalah metode studi pustaka. Penelitian ini dilakukan di perusahaan subsektor investment company di Bursa Efek Indonesia pada periode 2015-2019, yang berjumlah 8 perusahaan sebagai sampel yang telah memenuhi kriteria. Teknik pengambilan sampel menggunakan teknik purposive sampling. Teknik analisis data yang digunakan adalah analisis statistik deskriptif, uji asumsi klasik dan analisis regresi linier berganda.

\section{Hasil dan Pembahasan}

\subsection{Hasil Penelitian}

Berdasarkan kriteria yang telah ditetapkan dalam proses seleksi sampel, diperoleh 40 data penelitian,namun uji asumsi klasik pada uji normalitas menunjukkan adanya data tidak normal dikarenakan nilainya terlalu ekstrim atau selisih terlalu jauh. Sehingga harus menggunakan outlier boxplot SPSS untuk memenuhi syarat uji asumsi klasik sehingga diperoleh 36 sampel.

\subsubsection{Analisis Statistik Deskriptif}

Tabel 2. Analisis Deskriptif

Descriptive Statistics

\begin{tabular}{lr|r|r|r|r} 
& N & \multicolumn{1}{|c|}{ Minimum } & Maximum & \multicolumn{1}{c|}{ Mean } & Std. Deviation \\
\hline ESOP & 36 & 0 & 1 & .36 & .487 \\
\hline Leverage & 36 & .037 & 1.908 & .57724 & .395719 \\
\hline Ukuran Perusahaan & 36 & 15.696 & 27.886 & 20.24987 & 4.367355 \\
\hline Profitabilitas & 36 & -.305 & .247 & -.00885 & .093901 \\
\hline Valid N (listwise) & 36 & & & & \\
\hline Sumbr : data din & & & &
\end{tabular}

Sumber : data diolah, 2020

Berdasarkan pada tabel, jumlah data dari penelitian ini yang digunakan berjumlah 36 unit analisis. Dari hasil analisis statistik deskriptif selama periode pengamatan meunjukkan bahwa Variabel ESOP (X1) memiliki nilai minimum sebesar 0, yang memiliki arti bahwa nilai terendah pada variabel ESOP adalah sebesar 0 dan nilai maksimum sebesar 1, yang memiliki arti bahwa nilai tertinggi dari variabel ESOP adalah sebesar 1, Rata rata nilai ESOP pada perusahaan subsektor invetment company sebesar 0,36 dan standar deviasi 0,487 , yang artinya variasi pada data ESOP sebesar 0,487.

Variabel Leverage (X2) memiliki nilai minimum sebesar 0,037 yang dimiliki oleh 
perusahaan Pool Advista Indonesia Tbk (POOL) ditahun 2017, artinya perbandingan antara total hutang dengan total aset perusahaan POOL mengalami penurunan sebesar 0,037 satuan. Nilai maksimum Leverage sebesar 1,908 yang dimiliki oleh perusahaan Bakrie \& Brothers Tbk (BNBR) ditahun 2017, yang berarti perbandingan antara total hutang dengan total aset perusahaan BNBR tahun 2017 mengalami peningkatan sebesar 1,908. Rata rata Leverage sebesar 0,057 dan standar deviasi yang dimiliki sebensar 0,39 , yang artinya variasi pada data Leverage sebesar 0,39.

Variabel Ukuran Perusahaan (X3) memiliki nilai minimum sebesar 15,696 yang dimiliki oleh perusahaan Global Medicom Tbk (BMTR) ditahun 2016, artinya logaritma natural total aset perusahaan BMTR sebesar 15,69 satuan. Nilai maksimum ukuran perusahaan sebesar 27,88 yang dimiliki oleh perusahaan Pool Advista Indonesia (POOL) ditahun 2015, ini bararti nilai logaritma natural total aset perusahaan POOL tahun 2015 sebesar 27,88 satuan. Rata rata nilai ukuran perusahaan pada perusahaan subsektor investment company sebesar 20,24 dan standar deviasi yang dimiliki sebesar 4,36, yang artinya variasi pada data ukuran perusahaan sebesar 4,36.

Variabel Profitabilitas (Y) memiliki nilai minimum sebesar $-0,30$ yang dimiliki oleh perusahaan Saratoga Investama Sedaya Tbk (SRTG) di tahun 2018, ini berarti perbandingan laba bersih dengan total aset perusahaan SRTG tahun 2018 mengalami penurunan sebesar -0,030 satuan. Nilai maksimum Profitabilitas sebesar 0,24 yang dimiliki oleh perusahaan Pool Advista Indonesia (POOL) tahun 2017, ini berarti perbandingan laba bersih dnegan total aset perusahaan POOL tahun 2018 mengalami peningkatan sebesar 0,24 satuan. Rata rata nilai profitabilitas perusahaan pada perusahaan subsektor investment company sebesar -0,008 dan memiliki standar deviasi sebesar 0,093,yang artinya variasi pada data profitabilitas sebesar 0,093.

\subsubsection{Uji Asumsi Klasik Uji Normalitas}

\begin{tabular}{|c|c|c|}
\hline \multicolumn{3}{|c|}{ Tabel 3. Hasil Uji Normalitas } \\
\hline \multicolumn{3}{|c|}{ One-Sample Kolmogorov-Smirnov Test } \\
\hline & & $\begin{array}{c}\text { Unstandardized } \\
\text { Residual }\end{array}$ \\
\hline$N$ & & 36 \\
\hline \multirow{2}{*}{ Normal Parametersa,b } & Mean & .0000000 \\
\hline & Std. Deviation & .08430142 \\
\hline \multirow{3}{*}{ Most Extreme Differences } & Absolute & .141 \\
\hline & Positive & .098 \\
\hline & Negative & -.141 \\
\hline Test Statistic & & .141 \\
\hline Asymp. Sig- (z-tailed) & & $.069^{\circ}$ \\
\hline
\end{tabular}

Sumber : data diolah, 2020

Pada uji Normalitas yang digunakan adalah uji Kolmogorov-Smirnov Z (I-Sample K-S) yan dapat dilihat pada tabel diatas yang menunjukkan hasil dari uji analisis Kolmogorov - Smirnov yakni diperoleh nilai Asymp. Sig. (2-tailed) (0.069) yang berarti lebih besar dari level of significant $(0,05)$ maka dapat disimpulkan bahwa regresi pada penelitian ini berdistribusi normal.

\section{Uji Multikoloniearitas}

Tabel 4. Hasil Uji Multikoloniearitas

\section{Coefficients ${ }^{a}$}

\begin{tabular}{llll}
\multirow{2}{*}{ Model } & \multicolumn{3}{c}{$\begin{array}{c}\text { Collinearity Statistics } \\
\text { Tolerance }\end{array}$} \\
\hline \multirow{2}{*}{1} & VIF \\
\cline { 2 - 4 } & (Constant) & & \\
\cline { 2 - 4 } & ESOP & .964 & 1.037 \\
\cline { 2 - 4 } & Leverage & .957 & 1.045 \\
\cline { 2 - 4 } & Ukuran Perusahaan & .960 & 1.041 \\
\hline
\end{tabular}

a. Dependent Variable: Profitabilitas

Sumber :data diolah,2020

Berdasarkan tabel dari hasil uji Koefisien Tolerance semua variabel lebih besar dari 0,10 dan Nilai VIF yang lebih kecil dari 10. Hasil ini mengindikasikan bahwa tidak terdapat gejala multikolinearitas dari model regresi yang dibuat sehingga pada model regresi ini ditemukan korelasi 
antar variabel bebas.

\section{Uji Autokorelasi}

Tabel 5. Hasil Uji Autokorelasi

\begin{tabular}{|c|c|c|c|c|c|}
\hline \multicolumn{6}{|c|}{ Model Summary } \\
\hline Model & $\mathbf{R}$ & R Square & $\begin{array}{l}\text { Adjusted R } \\
\text { Square }\end{array}$ & $\begin{array}{l}\text { Std. Error of } \\
\text { the Estimate }\end{array}$ & Durbin-Watson \\
\hline 1 & $.440^{\mathrm{a}}$ & .194 & .118 & .088165 & 1.747 \\
\hline
\end{tabular}

a. Predictors: (Constant), Ukuran Perusahaan, ESOP, Leverage

b. Dependent Variable: Profitabilitas

Sumber : data diolah, 2020

Dari hasil uji menunjukkan nilai Durbinwatson (DW) pada tabel menunjukkan bahwa nilai DW sebesar 1,747 dengan nilai Du untuk sampel 36 dengan 3 variabel bebas adalah1,654 dan nilai 4-Du adalah 2,346. Oleh karena nilai $\mathrm{Du}<\mathrm{DW}<4$ -
$\mathrm{Du}(1,654<1,747<2,346)$, maka pada pengujian dengan DW tidak terdapat adanya autokorelasi sehingga model regresi yang digunakan tidak terdapat adanaya gejala autokorelasi.

\section{Uji Heteroskedasitas}

Tabel 6. Hasil Uji Heteroskedassitas

\begin{tabular}{llr}
\multicolumn{2}{l}{ Coefficients } \\
Model & & \multicolumn{1}{c}{ Sig. } \\
\hline 1 & (Constant) & .635 \\
\cline { 2 - 3 } & ESOP & .918 \\
\cline { 2 - 3 } & Leverage & .602 \\
\cline { 2 - 3 } & Ukuran Perusahaan & .086 \\
\hline
\end{tabular}

a. Dependent Variable: abs_res

Sumber : data diolah, 2020

Dari tabel diatas menunjukkan hasil dari uji heteroskedasitas dengan metode glejser yakni hasil dari nilai signifikansi lebih besar dari 0,005

\subsubsection{Analisis Regresi Linear Berganda}

Tabel 7. Tabel Hasil Analisis Regresi Linear Berganda

\section{Coefficients $^{\mathrm{a}}$}

\begin{tabular}{|c|c|c|c|c|c|c|}
\hline & & \multicolumn{2}{|c|}{$\begin{array}{l}\text { Unstandardized } \\
\text { Coefficients }\end{array}$} & \multirow{2}{*}{$\begin{array}{c}\text { Standardized } \\
\text { Coefficients } \\
\text { Beta }\end{array}$} & \multirow[b]{2}{*}{$\mathbf{t}$} & \multirow[b]{2}{*}{ Sig. } \\
\hline \multicolumn{2}{|c|}{ Model } & $\mathrm{B}$ & Std. Error & & & \\
\hline \multirow[t]{4}{*}{1} & (Constant) & .063 & .078 & & .807 & .426 \\
\hline & ESOP & .027 & .031 & .139 & .860 & .396 \\
\hline & Leverage & -.105 & .039 & -.443 & -2.730 & .010 \\
\hline & Ukuran Perusahaan & -.001 & .003 & -.047 & -.290 & .773 \\
\hline
\end{tabular}

a. Dependent Variable: Profitabilitas

Sumber : data diolah,2020

Berdasarkan hasil dari analisis dapat disusun persamaan regresi sebagai berikut:

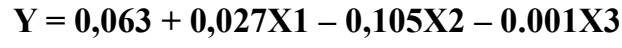

Koefisien regresi ESOP $(\mathrm{X} 1)=0,027$. Nilai koefisien regresi ESOP yang positif menunjukkan adanya hubungan yang searah terhadap profitabilitas artinya jika terjadi penambahan satu yang berarti model regresi bebas dari gejala heteroskedasitas. 
$-0,0001$. Nilai kefisien regresi ukuran perusahaan yang negatif menunjukkan adanaya hubungan yangg tidak searah terhadap profitabilitas artinya jika ukuran perusahaan terjadi penambahan satu persen maka profitabilitas akan menurun sebesar $0,01 \%$ dengan asumsi variabel independen lain.

\section{Uji Hipotesis}

Uji t

Table 8. Hasil Uji $t$

Coefficients $^{\mathrm{a}}$

\begin{tabular}{l|r|r|r|r|r} 
& \multicolumn{2}{c|}{$\begin{array}{c}\text { Unstandardized } \\
\text { Coefficients }\end{array}$} & $\begin{array}{c}\text { Standardized } \\
\text { Coefficients }\end{array}$ & & \\
Model & $\mathrm{B}$ & Std. Error & Beta & \multicolumn{1}{c|}{$\mathbf{t}$} & \multicolumn{1}{c}{ Sig. } \\
\hline 1 (Constant) & .063 & .078 & & .807 & .426 \\
\hline ESOP & .027 & .031 & .139 & .860 & .396 \\
\hline Leverage & -.105 & .039 & -.443 & -2.730 & .010 \\
\hline Ukuran Perusahaan & -.001 & .003 & -.047 & -.290 & .773 \\
\hline
\end{tabular}

a. Dependent Variable: Profitabilitas

Sumber : data diolah,2020

Pada penelitian ini menggunaan SPSS Ver.26, dapat kita ketahui dari tabel menunjukkan pada pengujian hipotesis 1 (H1) dengan uji $t$ diketahui nilai signifikansi untuk pengaruh ESOP (X1) terhadap Profitabilitas (Y) adalah sebesar $0,426>0,05$ sehingga dapat disimpulkan bahwa H1 ditolak yang berarti tidak terdapat pengaruh variabel X1 terhadap Y.

Pada pengujian hipotesis 2 (H2) dengan uji $\mathrm{t}$ diketahui nilai signifikansi untuk pengaruh Leverage (X2) terhadap Profitabilitas (Y) adalah sebesar $0,010<0,05$ sehingga dapat disimpulkan bahwa $\mathrm{H} 2$ diterima yang berarti terdapat adanya pengaruh dari variabel $\mathrm{X} 2$ terhadap $\mathrm{Y}$.

Pengujian hipotesis 3 (H3) dengan mengunakan uji t diketahui nilai signifikansi untuk pengaruh Ukuran Perusahaan (X3) terhadap Profitabilitas (Y) adalah sebesar $0,773>0,05$ sehingga dapat disimpulkan bahwa $\mathrm{H} 3$ ditolak yang berarti tidak terdapat adanya pengaruh variabel X3 terhadap

$\mathrm{Y}$.

Uji F

Tabel 9. Hasil Uji F

\begin{tabular}{|c|c|c|c|c|c|}
\hline \multicolumn{6}{|c|}{ ANOVA $^{\mathrm{a}}$} \\
\hline Model & $\begin{array}{c}\text { Sum of } \\
\text { Squares }\end{array}$ & df & Mean Square & $\mathbf{F}$ & Sig. \\
\hline 1 Regression & .060 & 3 & .020 & 2.568 & $.072^{b}$ \\
\hline Residual & .249 & 32 & .008 & & \\
\hline Total & .309 & 35 & & & \\
\hline
\end{tabular}

a. Dependent Variable: Profitabilitas

b. Predictors: (Constant), Ukuran Perusahaan, ESOP, Leverage

Sumber : data diolah,2020

Pada pengujian hipotesis 4 (H4) ,berdasarkan hasil dari tabel Output diketahui nilai signifikansi untuk pengaruh $\mathrm{X} 1, \mathrm{X} 2$, dan $\mathrm{X} 3$ secara simultan terhadap $\mathrm{Y}$ adalah sebesar $0.072>$
0,05 dan nilai $\mathrm{F}$ hitung $2,568<2,89$ sehingga dapat disimpulkan bahwa $\mathrm{H} 4$ ditolak yang berarti tidak terdapat adanya pengaruh $\mathrm{X} 1, \mathrm{X} 2$ dan $\mathrm{X} 3$ secara simultan terhadap Y.

\section{Uji Koefisien Diterminasi $\left(\mathbf{R}^{2}\right)$}

Tabel 10. Hasil Uji Koefisien Determinasi

Model Summary ${ }^{b}$

\begin{tabular}{|c|c|c|c|c|}
\hline \multicolumn{5}{|c|}{ Model Summary $^{b}$} \\
\hline Model & $\mathbf{R}$ & R Square & $\begin{array}{l}\text { Adjusted R } \\
\text { Square }\end{array}$ & $\begin{array}{l}\text { Std. Error of } \\
\text { the Estimate }\end{array}$ \\
\hline 1 & $.440^{\mathrm{a}}$ & .194 & .118 & .088165 \\
\hline
\end{tabular}


Pada tabel uji koefisien diterminasi berdasarkan hasil Output diketahui nilai R square sebesar 0,194, hal ini mengandung arti bahwa pengaruh variabel $\mathrm{X} 1, \mathrm{X} 2$ dan $\mathrm{X} 3$ secara simultan terhadap variabel $\mathrm{Y}$ adalah sebesar 19,4\%, sedangkan sisanya $80,6 \%$ dijelaskan oleh variabel lain di luar model penelitian.

\subsection{Pembahasan}

Pada penelitian yang telah dilakukan, maka dapat dijelaskan sebagai berikut

Tabel 11. Ikhtisar Hasil Analisis Data

\begin{tabular}{|l|l|l|l|l|}
\hline Variabel Independen & $\begin{array}{l}\text { Koefisien } \\
\boldsymbol{\beta}\end{array}$ & Sig & Keterangan & Hipotesis \\
\hline ESOP & .027 & .396 & Tidak berpengaruh & ditolak \\
\hline Leverage & -.105 & .010 & Berpengaruh & diterima \\
\hline Ukuran Perusahaan & -.001 & .773 & Tidak berpengaruh & ditolak \\
\hline $\begin{array}{l}\text { ESOP, Leverage, dan } \\
\begin{array}{l}\text { Ukuran Perusahaan } \\
\text { secara simultan }\end{array}\end{array}$ & - & .072 & Tidak berpengaruh & ditolak \\
\hline
\end{tabular}

Sumber : data diolah,2020

\subsubsection{Pengaruh Employee Stock Ownership Program (ESOP) terhadap profitabilitas (ROA)}

Hasil penelitian ini menunjukkan bahwa Employee Stock Ownership Program (ESOP). Hal ini dibuktikan dengan hasil uji t yang menunjukkan bahwa nilai signifikansi sebesar 0,396, sehingga nilai signifikansi lebih besar dari nilai 0,05 , $(0,396>0,5)$, jadi hipotesis yang menyatakan bahwa Employee Stock Ownership Program (ESOP) mempunyai pengaruh terhadap Profitabilitas (ROA) H1 ditolak dan $\mathrm{H} 0$ diterima. Hal ini berarti Employee Stock Ownership Program (ESOP) belum mampu memengaruhi profitabilitas pada perusahaan subsektor Investment Company.

Hasil penelitian dengan Agency theory dan teori sinyal, dimana dalam Agency theory menyatakan dengan adanya ESOP diharapkan mampu meningkatkan loyalitas pengelola perusahaan (agen) kepada pemilik perusahaan (prinsipal) dalam meningkatkan profitabilitas, dalam teori sinyal pula ESOP tidak memberikan pengaruh dalam kontribusi mengenai informasi profitabilitas suatu perusahaan dalam menilai kondisi suatu perusahaan, antara hubungan pengelola dengan pemilik perusahaan .Hasil penelitian ini mendukung penelitian yang telah dilakukan oleh (Isbanah, 2015) yakni ESOP tidak berpengaruh terhadap ROA, hasil penelitian ini juga bertolak belakang dengan (Yunita, 2018) yang menyatakan bahwa dari hasil penelitiannya menunjukkan adanya pengaruh yang signifikan terhadap Return On Asset (ROA).

\subsubsection{Pengaruh Leverage terhadap Profitabilitas (ROA) \\ Hasil penelitian ini menunjukkan bahwa} Leverage mempunyai pengaruh yang signifikan terhadap profitabilitas (ROA). Hal ini dibuktikan dengan hasil uji t yang menunjukkan bahwa nilai signifikansi sebesar 0,010, sehingga dapat diketahui nilai signifikansi lebih lebih kecil dari nilai $0,05 \quad(0,010<0,05)$, jadi hipotesis yang menyatakan bahwa Leverage berpengaruh terhadap profitabilitas (ROA) $\mathrm{H} 2$ diterima dan $\mathrm{H} 0$ ditolak. Hal ini berarti Leverage terbukti mampu memengaruhi profitabilitas pada perusahaan subsektor Investment Company. Dalam penelitian ini menunjukkan bahwa setiap penambahan satu persen leverage maka ROA akan mengalami penurunan sebesar 10,5\%. Hal tersebut menunjukkan bahwa semakin meningkatnya leverage menyebabkan laba perusahaan atas aset yang dimiliki akan menurun. Perusahaan harus bisa mengelola hutang dengan baik sehingga hutang perusahaan tidak terus meningkat yang dapat menyebabkan laba perusahaan tidak maksimal.

Hasil penelitian dengan Agency theory dan teori sinyal, dimana agen sebagai pihak yang dipekerjakan oleh prinsipal dipercaya memegang wewenang dalam melakukan pengambilan keputusan untuk mengolah laba perusahaan termasuk sumber dana apa yang sebaiknya dibutuhkan perusahaan dalam meningkatkan profitabilitas yakni salah satunya Leverage, pada teori sinyal pula leverage merupakan salah satu faktor yang berpengaruh dalam memberikan informasi kepada investor terhadap profitabilitas suatu perusahaan. Hasil penelitian ini pendukung penelitian yang telah dilakukan oleh (Isbanah, 2015) yang menyatakan dari hasil penelitiannya bahwa Leverage berpengaruh dan signifikan terhadap kinerja keuangan perusahaan, hasil penelitian ini juga bertolak belakang dengan hasil penelitian yang telah dilakukan oleh (Istyawati \& Purwohandoko, 2019) yang menyatakan bahwa Leverage tidak berpengaruh terhadap profitabilitas.

\subsubsection{Pengaruh Ukuran Perusahaan terhadap Profitabilitas (ROA)}

Hasil penelitian yang menunjukkan bahwa ukuran perusahaan tidak mempunyai pengaruh 
yang signifikan terhadap profitabilitas (ROA). Hal ini dibuktikan dengan hasil uji t yang menunjukkan bahwa nilai signifikansi sebesar 0,773 ,sehingga dapat diketahui nilai signifikansi lebih lebih besar dari nilai $0,05(0,773>0,05)$, jadi hipotesis yang menyatakan bahwa Ukuran Perusahaan berpengaruh terhadap profitabilitas (ROA) H3 ditolak dan H0 diterima. Hal ini berarti ukuran perusahaan belum mampu memengaruhi profitabilitas pada perusahaan subsektor Investment Company.

Hasil penelitian dengan Agency theory dan teori sinyal, yakni skala ukuran perusahaan ditentukan oleh langkah manajemen untuk mengelola laba perusahaan sebaik mungkin, yang mana kita ketahui perusahaan dengan skala besar belum tentu memiliki kinerja perusahaan yang baik pula dalam meningkatkan profitabilitasnya. Hasil penelitian ini pendukung penelitian yang telah dilakukan (Istyawati \& Purwohandoko, 2019) yang menyatakan bahwa hasil penelitiannya menunjukkan bahwa ukuran perusahaan tidak berpengaruh dan signifikan terhadap profitabilitas. Hasil penelitian ini bertolak belakang dengan penelitian yang dilakukan (Dewi \& Candradewi, 2018) yang menyatakan bahwa hasil penelitiannya menunjukkan bahwa ukuran perusahaan berpengaruh positif dan signifikan terhadap kinerja keuangan perusahaan.

4.2.4. Pengaruh Employee Stock Ownership Program (ESOP), Leverage dan ukuran perusahaan secara simultan terhadap profitabilitas

Pengaruh variabel variabel independen Employee Stock Ownership Program (ESOP), Leverage dan Ukuran Perusahaan Secara bersama sama terhadap variabel dependen yaitu profitabilitas (Return On Asset) pada perusahaan subsektor Investment company yang terdaftar di BEI periode 2015 sampai dengan 2019. Dapat diketahui dengan melakukan uji $\mathrm{F}$ dengan menggunakan metode SPSS ver.26. dari hasil uji $\mathrm{F}$ menunjukkan nilai signifikansi sebesar 0.072 , yang berarti nilai dari uji $\mathrm{F}$ lebih besar dari nilai 0,05 $(0,072>0,05)$. hasil dari uji $\mathrm{F}$ tersebut menunjukkan bahwa variabel Employee Stock Ownership Program (ESOP), Leverage dan Ukuran Perusahaan secara simultan tidak berpengaruh terhadap Profitabilitas (ROA) yang berarti $\mathrm{H} 4$ ditolak dan $\mathrm{H} 0$ diterima.

\section{Kesimpulan dan Saran}

\subsection{Kesimpulan}

Berdasarkan rumusan masalah dari hasil pembahasan yang telah dijelaskan, maka kesimpulan dari penelitian ini yakni sebagai berikut:

1. Employee Stock Ownership Program (ESOP) tidak berpengaruh dan signifikan terhadap
Profitabilitas (ROA) perusahaan subsektor Investment Company yang terdaftar di BEI periode 2015-2019.

2. Leverage berpengaruh dan signifikan terhadap profitabilitas (ROA) perusahaan subsektor investment company yang terdaftar di BEI periode 2015-2019.

3. Ukuran Perusahaan tidak berpengaruh terhadap Profitabilitas (ROA) perusahaan subsektor Investment Company yang terdaftar di BEI periode 2015-2019.

4. Employee Stock Ownership Program (ESOP), Leverage, Ukuran Perusahaan tidak berpengaruh secara simultan terhadap profitabilitas.

\subsection{Saran}

Berdasarkan dari hasil penelitian yang telah dilakukan maka saran yang dapat disampaikan sebagai berikut :

1. Bagi akademis, penelitian ini hanya sebatas variabel Employee Stock Ownership Program (ESOP), Leverage, Ukuran Perusahaan. disarankan untuk peneliti selanjutnya untuk menambah variabel variabel lain yang belum dicantumkan pada penelitian ini, seperti variabel likuiditas, pertumbuhan penjualan, perputaran modal kerja, dan lain lain. Dengan menambah variabel variabel bebas lainnya pada penelitian lain diharapkan bisa memperluas penelitian ini. Pada penelitian selanjutnya juga diharapkan memperpanjang atau menambah periode penelitian.

2. Bagi pihak manajemen perusahaan subsektor investment company, disarankan agar memperhatikan variabel Leverage karena pada penelitian ini terbukti Leverage berpengaruh dan signifikan terhadap profitabilitas.

3. Bagi investor, dalam menilai kinerja suatu perusahaan diharapkan para investor maupun calon investor sebaiknya untuk tidak hanya terfokus pada penerapan ESOP, Leverage maupun ukuran perusahaan dalam berinvestasi karena dalam suatu perusahaan dengan skala besar dan perusahaan yang sudah menerapkan ESOP belum tentu memiliki kinerja keuangan yang baik pula.

\section{Daftar Pustaka}

Budiman, A., \& Wahidahwati. (2017). Pengaruh Harga Eksekusi Dan ESOP Terhadap Kinerja Perusahaan Dengan Moderasi Kepemilikan Manajerial. Jurnal Ilmu \& Riset Akuntansi, Vol. 6.

Dewi, N. W. A. M., \& Candradewi, M. R. (2018). Pengaruh Employee Stock Ownership Plan, Leverage , Dan Ukuran Perusahaan Terhadap Kinerja Keuangan Perusahaan. Jurnal Manajemen Unud, 7(9), 4774-4802. 
Dwiyanthi, N., \& Sudiartha, G. (2017). Pengaruh Likuiditas dan Perputaran Modal Kerja terhadap Profitabilitas pada Perusahaan Manufaktur Sektor Industri Barang Konsumsi. E-Jurnal Manajemen Universitas Udayana, 6(9), 4829-4856.

Haosana, Y., \& Hatane, S. E. (2015). Peranan Employess Stock Ownership Program , Human Cost Efficiency Dan Total Asset. Business Accounting Review, 3(1), 456-465.

Hastuti, R. K. (2020). OJK Kembali Temukan 99 Investasi Bodong, Nih Daftarnya! CNBC Indonesia.

Hidayat, M., \& Hairi, M. I. A. (2016). Pengaruh Perencanaan Pajak dan Modal Intelektual terhadap Nilai Perusahaan pada Perusahaan Jasa Keuangan yang Terdaftar di Bursa Efek Indoensia Periode 2009-2013. Jurnal Ilmiah Ekonomi Global Masa Kini, 7(2), 23-29.

Isbanah, Y. (2015). Pengaruh Esop, Leverage, and Ukuran Perusahaan Terhadap Kinerja Keuangan Perusahaan Di Bursa Efek Indonesia. Jurnal Riset Ekonomi Dan Manajemen, 15(1), 28.

Istyawati, N., \& Purwohandoko. (2019). Pengaruh Leverage, Likuiditas, Ukuran Perusahaan, Inflasi Dan Profitabilitas (Studi Pada Perusahaan Sektor Properti, Real Estate and Building Contruction Di Bursa Efek Indonesia). Ilmu Manajemen, 7, 668-676.

Jayani, D. H. (2020). Realisasi Investasi Indonesia 2019 Naik 48,4\% dalam 5 Tahun. Databoks.Katadata.Co.Id.

Kartikasari, A. A. A. I., \& Astika, I. B. P. (2015). Pengaruh Harga Eksekusi Dan Jumlah Opsi Saham Karyawan ( Esop ) Pada Kinerja Perusahaan Fakultas Ekonomi Dan Bisnis Universitas Udayana ( Unud ), Bali , Indonesia. E-Jurnal Akuntansi Universitas Udayana, 3, 698-712.

Meiriasari, V. (2017). Pengaruh Corporate Governance, Kepemilikan Keluarga, Kepemilikan Institusional dan Ukuran Perusahaan (Firm Size) terhadap Biaya Utang. Jurnal Ilmiah Ekonomi Global Masa Kini, 8(1), 28-34.

Pangestuti, C. D. A., \& Oetomo, H. W. (2016). Pengaruh Perputaran Modal Kerja , Ukuran Perusahaan, Operating Leverage , Financial Leverage Terhadap Profitabilitas. Jurnal Ilmu Dan Riset Manajemen, 5(7), 1-18.

Patmawati, P. (2017). Pengaruhcorporate Social Responsibility Disclosure dan Good Corporate Governance terhadap Nilai Perusahaan dengan Kinerja Keuangan Sebagai Variabel Intervening. Jurnal Ilmiah Ekonomi Global Masa Kini, 8(1), 46-58.

Pebriani, R. A., Munandar, A., Veronica, M., \&
Meihazura, Y. (2020). Pengaruh Perputaran Piutang dan Perputaran Persediaan Terhadap Profitabilitas Pada Perusahaan Sub Sektor Perdagangan Eceran yang Terdaftar Di Bursa Efek Indonesia (Bei) Periode 2014-2018. Jurnal Keuangan Dan Bisnis, 18(1), 116.

Pratama, I. G. B. A., \& Wiksuana, I. G. B. (2016). Pengaruh Leverage dan Ukuran Perusahaan terhadap Nilai Perusahaan Dengan Profitabilitas sebagai Variabel Mediasi. EJurnal Manajemen Universitas Udayana, 5(5), 1338-1367.

Pribadi, A. R. (2018). Rasio-Rasio Keuangan dalam Memprediksi Kecurangan. ULTIMA Accounting, 10(1), 66-76.

Purnamasari, E. D. (2017). Analisis Pengaruh Laverage terhadap Profitabilitas Perusahaan yang Termasuk LQ45 Periode Agustus 2015Januari 2016 di Bursa Efek Indonesia. Jurnal Ilmiah Ekonomi Global Masa Kini, 8(1), 4145.

Putra, A., \& Badjra, I. (2015). Pengaruh Leverage, Pertumbuhan Penjualan Dan Ukuran Perusahaan Terhadap Profitabilitas. E-Jurnal Manajemen Universitas Udayana, 4(7), 249411.

Setyaningrum, A. N. (2016). Pengaruh ESOP terhadap Kualitas Implementasi Corporate Governance dan Kinerja Perusahaan. Jurnal Ilmiah Mahasiswa FEB, 1(1), 1-26.

Sugiyono, P. dr. (2017). Metode Penelitian Kuantitatif, Kualitatif, danRgD. Alfabeta cv.

Sukmayanti, N. W. P., \& Triaryati, N. (2019). Pengaruh Struktur Modal, Likuiditas Dan Ukuran Perusahaan Terhadap Profitabilitas Pada Perusahaan Property Dan Real Estate. E-Jurnal Manajemen Universitas Udayana, $8(1), 7132-7162$.

Supriadi, I. (2020). Metode Riset Akuntansi. deeppublish.

Surya, S., Ruliana, R., \& Soetama, D. R. (2017). Pengaruh Perputaran Kas dan Perputaran Persediaan Terhadap Profitabilitas. Akuntabilitas, 10(2), 313-332.

Trianto, A. (2018). Analisis laporan keuangan sebagai alat untuk menilai kinerja keuangan perusahaan pada PT. Bukit Asam (Persero) Tbk Tanjung Enim. Jurnal Ilmiah Ekonomi Global Masa Kini, 8(3), 1-10

Wijayanti, R. (2016). Pengaruh Pengungkapan Sustainability Report Terhadap Kinerja Keuangan Perusahaan. National Institute Economic Review, 59(1), 4-21.

Yunita, N. A. (2018). Pengaruh Employee Stock Ownership (ESOP) terhadap Profitabiliras pada Perusahaan yang Terdaftar di Bursa Efek Indonesia. Jurnal Visioner \& Strategis, 7(1), 23-30. 